\title{
Ramipril and Valsartan as protective agents against some complications of an experimentally induced obesity in rats
}

\author{
Said Al-Dalaen ${ }^{1, *}$, Aiman Al-Qtaitat ${ }^{2}$, Samir Mahgoub ${ }^{3}$, Nedal Alnawaiseh ${ }^{4}$, Jehad Al-Shuneigat ${ }^{3}$, \\ Samih Sarayreh $^{3}$, Yousef Sarayreh ${ }^{1}$
}

${ }^{1}$ Department of Pharmacology, Faculty of Medicine, Mutah University, Karak, Jordan

${ }^{2}$ Department of Anatomy and Histology, Faculty of Medicine, Mutah University, Karak, Jordan

${ }^{3}$ Department of Biochemistry and Molecular Biology, Faculty of Medicine, Mutah University, Karak, Jordan

${ }^{4}$ Department of Public Health, Faculty of Medicine, Mutah University, Karak, Jordan

\section{Email address:}

aldalaensm@yahoo.com (Al-Dalaen S.), aimanaq2000@yahoo.com (Al-Qtaitat A.), samir_mhgb@yahoo.com (Mahgoub S.), Dr.Jehad@Mutah.edu.jo (Al-Shuneigat J.), sameeh_sarayreh@yahoo.com (Sarayreh S.), yousef_sar@hotmail.com (Sarayreh Y.)

\section{To cite this article:}

Said Al-Dalaen, Aiman Al-Qtaitat, Samir Mahgoub, Nedal Alnawaiseh, Jehad Al-Shuneigat, Samih Sarayreh, Yousef Sarayreh. Ramipril and Valsartan as Protective Agents against Some Complications of an Experimentally Induced Obesity in Rats. American Journal of Life Sciences. Vol. 2, No. 4, 2014, pp. 241-250. doi: 10.11648/j.ajls.20140204.18

\begin{abstract}
Objectives: Our work aimed to study the effect of experimentally induced obesity on the rate of advanced glycated end products (AGEs) formation and the activity of angiotensin converting enzyme (ACE) and its relation to oxidative stress and also to evaluate the protective effect of ramipril (an angiotensin converting enzyme inhibitor), valsartan [an angiotensin II blocker; AT1 receptor blocker), and their combination on these obese animals. Materials and Methods: The present study was conducted on ten female albino rats fed on standard chow as a control group and fifty obese animals received for sixteen weeks high fat diet alone or in concomitant combination with either ramipril $(2 \mathrm{mg} / \mathrm{kg} / \mathrm{day}$ or 0.25 $\mathrm{mg} / \mathrm{kg})$ or valsartan $(0.30 \mathrm{mg} / \mathrm{kg} / \mathrm{day})$ or the combination of both drugs $(0.25 \mathrm{mg} / \mathrm{kg}$ of ramipril and $0.30 \mathrm{mg} / \mathrm{kg}$ of valsartan daily for sixteen weeks). Blood, kidney and aortic AGEs, ACE activity and advanced oxidation protein products (AOPPs) were measured. Results: The obtained results showed increase in triacylglycerols (TGs) levels $(p<0.043)$ in the obese animals versus the control group. The total blood cholesterol (TC) and LDL-cholesterol (LDL-C) levels, also, were significantly higher $(\mathrm{p}<0.0001)$ in obese animals compared to the corresponding values in controls, with a significant reduction in their levels in all treated groups except in group IV ( $\mathrm{p}=.041)$ when compared to the control group. On the other hand, HDL-cholesterol (HDL-C) was significantly lower $(p<0.0001)$ in the obese animals compared to its level in the controls. The obese animals showed significant increase in their blood glucose and serum insulin levels when compared to the controls $[(p<0.037)$ and $(p<0.045)$, respectively]. The results, also, revealed that obesity was associated with a statistically significant increase in the blood, kidney and aortic tissue levels of AGEs, ACE and AOPPs compared to their corresponding values in the control group. Treatment with ramipril, valsartan and their combination caused significant reduction in serum and tissue levels of both AGEs and AOPPs when compared with the obese group. On the other hand, ACE activity was markedly reduced following the administration of ramipril alone or when it is combined with valsartan, while the administration of valsartan alone showed no significant effect on the activity of ACE when compared to the obese group. Moreover, combination of ramipril (at a submaximal antihypertensive dose of $0.25 \mathrm{mg} / \mathrm{kg} / \mathrm{day}$ ) with valsartan produce a marked reduction in all parameters examined compared to valsartan alone. Conclusion: combination of ramipril and valsartan showed more therapeutic effect compared to individual therapy with ACE inhibitor or AT1 receptor blocker.
\end{abstract}

Keywords: Ramipril, Valsartan, Obesity, AGE, ACE, AOPPs 


\section{Introduction}

Obesity is an independent risk factor for many diseases. The insulin resistance associated with obesity contributes to the development of many cardiovascular risk factors, including dyslipidemia, hypertension and type II diabetes. The rise in plasma insulin levels may elevate blood pressure levels by a variety of mechanisms, including increased sympathetic activity and sodium retention [1] [2]. Obesity induces changes in the renal medulla that result in activation of rennin angiotensin system that may also contribute to sodium retention and hypertension [3]. The rennin angiotensin system (RAS) is present in the vasculature and organs such as the heart and kidney, as well as adipocytes, where it is functionally active [4] [5]. Angiotensin converting enzyme (ACE) is a plasma membrane-bound zinc metallopeptidase, primarily residing on the surface of epithelial and endothelial cells, it has several functions related to the RAS. It is a dipeptidyl carboxypeptidase, releases C-terminal his-leu from decapeptide angiotensin I converting it into the powerful vasoconstrictor and salt retaining compound angiotensin II [6] [7]. ACE plays a key role in regulating blood pressure (BP) as well as fluid and electrolyte balance [8] [9]. Due to its effects on the vascular tone and the formation of atherosclerotic plaque, it has been demonstrated that RAS blockade, by either ACE inhibition or angiotensin receptor blockade, has distinct reno - protective and cardiovascular protective effects, but which of the two drug classes confers more protection is still a matter of debate [10].

There is evidence that there is a linkage between insulin resistance (IR) and glucose intolerance (IGT) in obese individuals to an increased risk of coronary heart disease (CHD) and atherosclerosis, but the mechanisms responsible for that are poorly understood [11]. One of the potential mechanisms by which hyperglycemia might contribute to CHD is through the formation of advanced glycated end products (AGEs) [12], which are heterogeneous group of compounds formed from nonenzymatic glycation of intracellular and extracellular proteins by hyperglycemia, participating in the many complications of diabetes [13]. The accumulation of AGEs will lead to tissue damage through a variety of mechanisms, including structural modification of proteins, accumulation of cellular responses via receptor specific for AGE proteins and the generation of reactive oxygen species [14] [13]. The receptors for AGEs (RAGE) are expressed by a variety of different cell types. AGE-RAGE interactions result in the generation of reactive oxygen species and nuclear factor $\kappa \beta$ activation in endothelial and smooth muscle cells, which could in turn contribute to the tissue damage and metabolic imbalances seen in diabetic complications [15]. Additionally a recent study has demonstrated the activation of NADPH oxidase by AGEs [16].

Oxidative stress is widely recognized as a key component in the development of many pathological complications. It is unknown whether it is an important link between hyperglycemia and its complications or whether it is a consequence of primary pathologic mechanisms [17]. For a long time, products of lipid peroxidation were considered as good markers for the evaluation of the degree of oxidative stress in an organism, however there are different evidences confirming the importance of advanced oxidation protein products (AOPPs) as markers of oxidative stress and the degree of protein damage in many pathological and disease conditions in living organisms [18] [19] [20]. AOPPs are the terminal products of protein exposure to the free radicals and once formed they act as endogenous oxidants [21]. Recent studies have demonstrated that inhibition of reactive oxygen species (ROS) in cultured bovine endothelial cells exposed to glucose interferes with multiple independent pathways of hyperglycemic damage, including nuclear factor $\kappa \beta(\mathrm{NF}-\kappa \beta)$ activation and formation of AGEs [22] [23].

\section{Materials and Methods}

\subsection{Animals}

A total of 60 Inbred mature female albino rat (Sprague Dawley strain), average weight $130-140 \mathrm{~g}$, were obtained from the animal facility of The Faculty of Medicine, Mutah University. They were maintained under standard conditions 12:12 light: dark cycle at room temperature $24 \pm 1{ }^{\circ} \mathrm{C}$, and $50 \% \pm 10 \%$ relative humidity. All animals were kept in wire mesh cages and drinking tap water ad libitum. The experiments were conducted according to the ethical norms approved by the Faculty Ethics Committee. The rats were randomly distributed in six groups (ten rats in each group):

Group I: received normal diet (rat chow) for 16 weeks (control group).

Group II: received high fat diet for 16 weeks.

Group III: received high fat diet and oral administration of ramipril $2 \mathrm{mg} / \mathrm{kg}$ daily for 16 weeks; this dose was administered as it produces blood pressure lowering effect [24].

Group IV: received high fat diet and oral administration of ramipril $0.25 \mathrm{mg} / \mathrm{kg}$ daily for 16 weeks; this dose was administered as a submaximal antihypertensive dose that produces blood pressure lowering effect [25].

Group V: received high fat diet and oral administration of valsartan $30 \mathrm{mg} / \mathrm{kg}$ daily for 16 weeks; this dose was administered as it decreases advanced glycated end products [26].

Group VI: received high fat diet and oral administration of ramipril $0.25 \mathrm{mg} / \mathrm{kg}$ and valsartan $30 \mathrm{mg} / \mathrm{kg}$ daily for 16 weeks.

The high fat formula was similar to that used by Lemmonnier [27], but the lard shortening was replaced by palm oil which contained the same proportion of saturated to polyunsaturated fatty acids [28].

\subsubsection{Sample Collection}

After 6 hours of fasting, the animals were anaesthetized 
by ether and while the heart is still beating, $3 \mathrm{ml}$ blood was collected via cardiac puncture. Blood samples were kept in plain glass clotting tubes, then serum was separated from blood clots by centrifugation and was stored in aliquots at $70^{\circ} \mathrm{C}$ until used for determination of glucose level, insulin level, lipid profile, serum AGEs, AOPPs and ACE activity. The animals were sacrificed according to the current animal care regulations; both kidneys and thoracic aorta were removed, washed three times in ice cold saline, and stored immediately at $-70^{\circ} \mathrm{C}$. They were used to determine tissue AGEs, AOPPs and ACE activity. Protein content within tissue homogenates was measured according to the method of Bradford [29].

\subsubsection{Blood Glucose}

Determination of blood glucose level was done by the glucose oxidase method [30].

\subsubsection{Insulin Level}

Quantitative determination of serum insulin level was done using ELISA [31].

\subsubsection{Serum AGEs}

Serum AGEs and the total protein content of all samples was measured and adjusted to $10 \mathrm{mg} / \mathrm{ml}$. Fluorescence was measured at $370 \mathrm{~nm}$ excitation and $440 \mathrm{~nm}$ emission using fluorescence spectrometer and expressed as relative fluorescence compared with that of $10 \mathrm{mg} / \mathrm{ml}$ bovine serum albumin (BSA) as standard [32].

\subsubsection{Tissue AGEs}

Tissues were homogenized in phosphate buffered saline, washed in chloroform/methanol solution, digested with type II collagenase at $37^{\circ} \mathrm{C}$ for 24 hours and then centrifuged at $6000 \mathrm{rpm}$ for 15 minutes. The hydroxyproline content was estimated by a colorimetric assay after hydrolyzing the supernatant using $\mathrm{HCl}(6 \mathrm{~mol} / \mathrm{l})$ [33]. The fluorescence of tissue AGE was measured spectrofluorometrically with excitation/emission of $370 / 440 \mathrm{~nm}$, the fluorescence values were corrected for collagenase blank, then they were expressed in arbitrary units (AU) per mg collagen, assuming that the fluorescence of native collagen with a concentration of $1 \mathrm{mg} / \mathrm{ml}$ equals one AU. The collagen content of samples was determined by an indirect method assuming that collagen contains $14 \%$ hydroxyproline [12].

\subsubsection{AOPPs}

Plasma and tissue levels of AOPPs were determined using semiautomated spectrophotometric method [34] on a microplate reader and were calibrated with chloramines-T solutions. As the absorbance of chloramines-T at $340 \mathrm{~nm}$ is linear within the range of $0-100 \mu \mathrm{mol} / \mathrm{L}$. AOPP concentrations were expressed as $\mu \mathrm{mol} / \mathrm{L}$ chloramines- $\mathrm{T}$ equivalents.

\subsubsection{ACE Activity}

Tissue was homogenized in $0.4 \mathrm{~mol} / 1$ borate $\mathrm{pH} 7.2$ containing $0.34 \mathrm{~mol} / \mathrm{l}$ sucrose and $0.9 \mathrm{~mol} / \mathrm{l} \mathrm{NaCl}(1 \mathrm{mg}$ tissue/ml). Homogenates were centrifuged at $3000 \mathrm{rpm}$ for 10 minutes; the supernatants were used for fluorimetric determination of ACE activity as described by Oleveira et al [35]. Briefly, serum samples and supernatants from homogenized tissues $(20 \mu \mathrm{l})$ were incubated with $480 \mu \mathrm{l}$ assay buffer containing $5 \mathrm{mmol} / \mathrm{l} \mathrm{Hip-His-Leu} \mathrm{in} 0.4 \mathrm{~mol} / \mathrm{l}$ sodium borate buffer with $0.9 \mathrm{~mol} / \mathrm{l} \mathrm{NaCl}, \mathrm{pH} 8.3$; sodium borate buffer with $0.1 \%$ Triton X-100 with $0.9 \mathrm{~mol} / 1 \mathrm{NaCl}$ $\mathrm{pH} 8.0$ for 30 minutes at $37^{\circ} \mathrm{C}$. The reaction was halted by adding $1.2 \mathrm{ml} 0.34 \mathrm{~N} \mathrm{NaOH}$. The product His-Leu was measured at $365 \mathrm{~nm}$ fluorimetrically at $365 \mathrm{~nm}$ excitation and $495 \mathrm{~nm}$ emission after addition of $100 \mu \mathrm{l} 0$ phthaldialdehyde $(20 \mathrm{mg} / \mathrm{ml})$ in methanol. This was followed by 10 minutes later by the addition of $200 \mu \mathrm{l} \mathrm{N}$ $\mathrm{HCl}$, then, centrifuged at $3000 \mathrm{rpm}$ for 10 minutes at room temperature. To correct for the intrinsic fluorescence of the tissues, blanks were made by adding the samples to the reaction after the addition of $\mathrm{NaOH}$. All experiments were performed in duplicate. The samples were assayed within 10- second intervals. The specificity of the assay was determined on the basis of inhibition of ACE activity with the compound enalaprilat MK-422 $(3 \mu \mathrm{mol} / \mathrm{l})$. ACE activity was related to tissue protein as measured by the method adopted by Bradford [29].

Lipid profile was quantified spectrophotometrically using kits supplied by BioMerieux Vitex Inc.

\subsection{Statistical Analysis}

The values of the measured parameters were expressed as mean $\pm \mathrm{SE}$. The difference between groups was determined using ANOVA test, $\mathrm{p}<0.05$ values were considered significant. All the statistical analyses were processed using Statistical Program of Social Sciences (SPSS) for windows, version 16.

\section{Results}

Initially there was no significant difference in body weight between the control group and all other groups. However following the 16 weeks, there was a statistically significant increase of $14.5 \%$ in the weight of the high fat diet groups of animals versus the control group. The study also, showed that obese animals exhibited marked dyslipidemia, in the form of increased triacylglycerols (TGs) levels $(80.29 \pm 0.46 \mathrm{mg} / \mathrm{dl}$ for group II) compared to the control group $(51.39 \pm 0.85)$, with no significant change ( $\mathrm{p}$ values were $0.929,0.940,0.828$ and 0.995 in groups III, IV, $\mathrm{V}$ and VI, respectively) in the levels of TGs in all treated groups compared to the obese untreated group. The total blood cholesterol (TC) and LDL-cholesterol (LDL-C) levels, also, were significantly higher $(\mathrm{p}<0.0001)$ in obese animals $(79.97 \pm 0.36 \mathrm{mg} / \mathrm{dl}$ and $40.97 \pm 0.64 \mathrm{mg} / \mathrm{dl}$, respectively) compared to the corresponding values in controls $(71.67 \pm 0.51 \mathrm{mg} / \mathrm{dl}$ and $33.25 \pm 0.30 \mathrm{mg} / \mathrm{dl}$, respectively), with a significant reduction in their levels in all treated groups except in group IV $(p=.041)$ when compared to the control group. On the other hand, HDL- 
cholesterol (HDL-C) was significantly lower $(\mathrm{p}<0.0001)$ in the obese animals $(20.97 \pm 0.64 \mathrm{mg} / \mathrm{dl})$ compared to its level in the controls $(28.29 \pm 0.26 \mathrm{mg} / \mathrm{dl})$, with no significant change ( $p$ values were $1,0.608,0.508$ and 1 in groups III,
IV, V and VI, respectively) when animals were treated with ramipril, valsartan or their combination. VLDL-cholesterol (VLDL-C) levels did not show statistically significant difference between all groups as shown in table (1)

Table 1. Lipid profile in studied groups ( $\mathrm{mg} / \mathrm{dl}$ ) expressed as mean $\pm S E$

\begin{tabular}{llllll}
\hline Parameter & Group I & Group II & Group III & Group IV & Group V \\
\hline TGs $(\mathrm{mg} / \mathrm{dl})$ & $51.39 \pm 0.85$ & $80.29 \pm 0.46 *$ & $77.99 \pm 1.98 *$ & $78.09 \pm 1.58 *$ & $77.39 \pm 1.43 *$ \\
TC $(\mathrm{mg} / \mathrm{dl})$ & $71.67 \pm 0.51$ & $79.97 \pm 0.36 *$ & $76.87 \pm 1.48$ & $76.77 \pm 0.69$ & $78.17 \pm 0.88 *$ \\
HDL-C $(\mathrm{mg} / \mathrm{dl})$ & $28.29 \pm 0.26$ & $20.97 \pm 0.64 *$ & $20.89 \pm 0.55 *$ & $19.49 \pm 0.31 *$ & $22.59 \pm 0.53 *$ \\
LDL-C $(\mathrm{mg} / \mathrm{dl})$ & $33.25 \pm 0.30$ & $40.97 \pm 0.64 *$ & $40.69 \pm 0.70 *$ & $40.15 \pm 0.68 *$ & $38.55 \pm 0.54 *$ \\
VLDL-C $(\mathrm{mg} / \mathrm{dl})$ & $10.93 \pm 0.22$ & $13.95 \pm 0.38 *$ & $14.43 \pm 0.54 *$ & $15.63 \pm 0.29 *$ & $14.74 \pm 0.22 *$ \\
\hline
\end{tabular}

* Significant when compared to the corresponding values in group I

The mean value of blood glucose in the control group was $131.68 \pm 0.5 \mathrm{mg} / \mathrm{dl}$, while the obese animals showed a significant elevation in their blood glucose levels as shown in table 2. Treatment with ramipril, valsartan, or their combination caused no significant decrease ( $p$ values were $0.102,0.070,0.997$ and 0.123 in groups III, IV, V and VI, respectively) in blood glucose level compared to obese group II. Similarly, obese animals showed statistically significant elevation in serum insulin level $(39.1 \pm 2.26$ $\mathrm{mIU} / \mathrm{ml})$ compared to the control group (19.6 \pm 0.30 $\mathrm{mIU} / \mathrm{ml})$, the treated animals with ramipril, valsartan or their combination showed no significant decrease in insulin levels (table 2)

Table 2. Comparison between blood glucose ( $\mathrm{mg} / \mathrm{dl})$ and insulin ( $\mathrm{mIU} / \mathrm{ml})$ levels in the studied groups (mean $\pm S E)$

\begin{tabular}{llllll}
\hline Parameter & Group I & Group II & Group III & Group IV & Group V \\
\hline Blood glucose & $131.39 \pm 0.5$ & $179.98 \pm 0.97 *$ & $168.38 \pm 1.93 * *$ & $172.09 \pm 1.9 *$ & $178.68 \pm 1.35 *$ \\
Insulin level & $19.6 \pm 0.3$ & $39.1 \pm 2.26 * *$ & $37.7 \pm 0.69 * *$ & $38.7 \pm 0.49 * *$ & $38.6 \pm 0.53 * *$ \\
\hline
\end{tabular}

* Significant when compared to the corresponding values in group I

\# Significant when compared to the corresponding values in group II

** Significant when compared to the corresponding values in group I

Table 3 represents the levels of advanced glycated end products (AGEs) in the serum, kidney and aortic tissues it showed that obesity was accompanied by a statistically significant increase in the blood, kidney and aortic tissues levels of AGEs $(59.52 \pm 0.58 \mathrm{AU} / \mathrm{ml}, 44.55 \pm 1.29 \mathrm{AU} / \mathrm{mg}$ collagen and $39.73 \pm 0.78 \mathrm{AU} / \mathrm{mg}$ collagen, respectively) compared to their corresponding values of the control group $(32.02 \pm 0.37 \mathrm{AU} / \mathrm{ml}, 20.25 \pm 0.36 \mathrm{AU} / \mathrm{mg}$ collagen and $18.63 \pm 0.26 \mathrm{AU} / \mathrm{mg}$ collagen, respectively). The treatment of the animals with ramipril, valsartan and their combination caused significant reduction in their levels both in serum and tissues compared to group II (figure, 1)

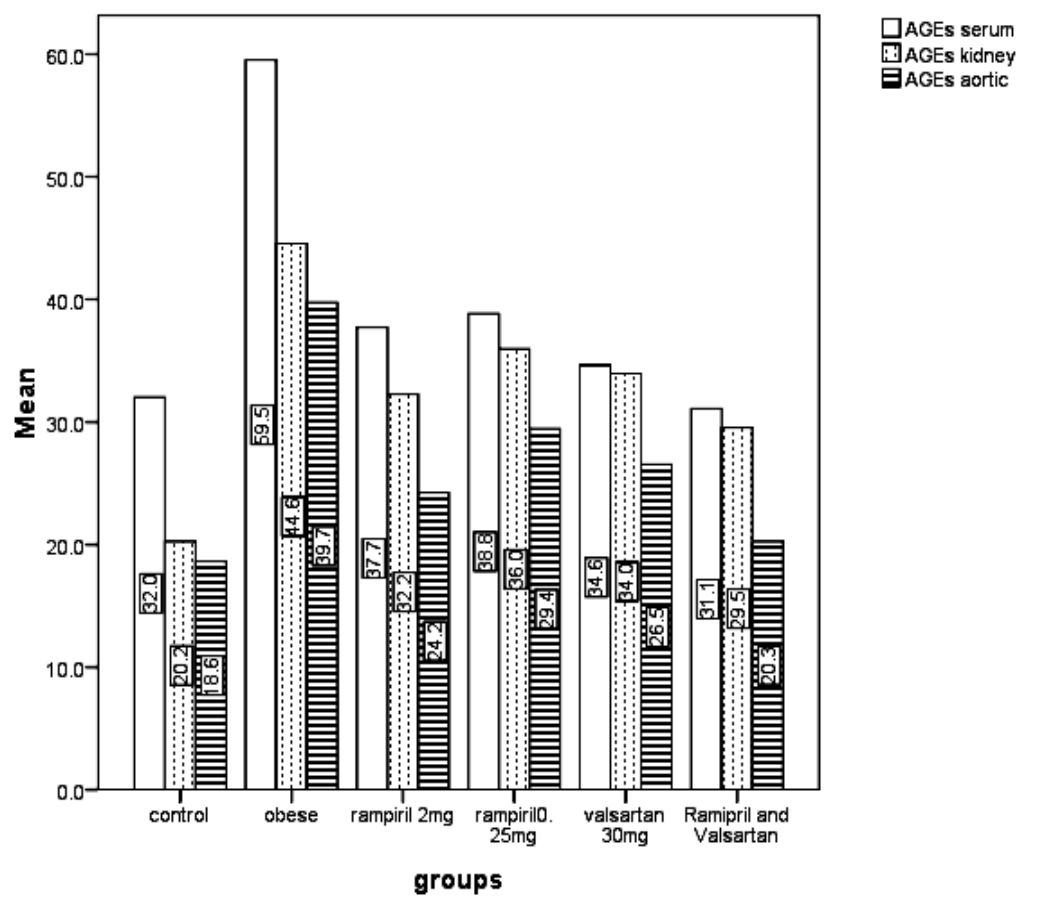

Figure 1. Levels of Advanced glycated end products (AGEs) in serum, kidney and aortic tissues in the studied groups 
Table 3. Levels of advanced glycated end products (AGEs) in serum (AU/ml), kidney and aortic tissues (AU/mg collagen) expressed as mean $\pm S E$

\begin{tabular}{lllllll}
\hline AGEs & Group I & Group II & Group III & Group IV & Group V & Group VI \\
\hline Serum & $32.02 \pm 0.37$ & $59.52 \pm 0.58^{*}$ & $37.72 \pm 0.81^{*}$ & $38.82 \pm 0.62 *$ & $34.62 \pm 0.3$ & $31.08 \pm 0.4$ \\
Kidney tissues & $20.25 \pm 0.34^{\#}$ & $44.55 \pm 1.3$ & $32.25 \pm 0.51^{\#}$ & $35.95 \pm 1.23^{\#}$ & $33.95 \pm 1.02^{\#}$ & $29.53 \pm 0.37^{\#}$ \\
Aortic tissues & $18.63 \pm 0.26$ & $39.73 \pm 0.78$ & $24.23 \pm 1.11$ & $29.43 \pm 0.49$ & $26.53 \pm 0.46$ & $20.26 \pm 0.45$ \\
\hline
\end{tabular}

* Significant when compared to the corresponding values in group I

\# Significant when compared to the corresponding values in group II

Table 4 and figure 2: showed statistically significant increase in the blood, kidney and aortic tissue levels of AOPPs $(58.62 \pm 0.88 \mu \mathrm{mol} / \mathrm{L}, 210.0 \pm 2.14 \mu \mathrm{mol} / \mathrm{mg}$ protein and $204.2 \pm 2.62 \mu \mathrm{mol} / \mathrm{mg}$ protein, respectively) versus their corresponding values in the control group $(22.12 \pm 0.23$ $\mu \mathrm{mol} / \mathrm{L}, \quad 108.0 \pm 1.46 \mu \mathrm{mol} / \mathrm{mg}$ protein and $119.6 \pm 1.12$ $\mu \mathrm{mol} / \mathrm{mg}$ protein, respectively). Treatment with ramipril, valsartan and their combination resulted in a significant reduction in their levels in both serum and tissues in comparison to group II.

Table 4. Levels of advanced oxidation protein products (AOPPS) in serum ( $\mu m o l / L)$, kidney and aortic tissues ( $\mu m o l / m g$ protein) expressed as mean \pm S.E

\begin{tabular}{|c|c|c|c|c|c|c|}
\hline AOPPs & Group I & Group II & Group III & Group IV & Group V & Group VI \\
\hline Serum & $22.12 \pm 0.23^{\&}$ & $58.62 \pm 0.88^{*} \&$ & $39.52 \pm 0.80$ *\#\& & $40.32 \pm 0.67^{* \#}$ & $37.92 \pm 0.50 * \# \&$ & $45.69 \pm 1.1^{* \# \&}$ \\
\hline Kidney tissues & $108.0 \pm 1.46^{\&}$ & $210.0 \pm 2.14 * \&$ & $150.5 \pm 1.11^{* \# \&}$ & $161.8 \pm 1.4^{* \#}$ & $159.0 \pm 1.26^{* \# \&}$ & $149.9 \pm 2.3^{* \# \&}$ \\
\hline Aortic tissues & $119.6 \pm 1.11^{\&}$ & $204.2 \pm 2.62 * \&$ & $134.0 \pm 2.59$ *\#\& & $128.6 \pm 1.54$ *\# & $128.6 \pm 1.54 * \# \&$ & $147.5 \pm 1.78^{* \# \&}$ \\
\hline
\end{tabular}

* Significant when compared to the corresponding values in group I

\# Significant when compared to the corresponding values in group II

\& Significant when compared to the corresponding values in group VI

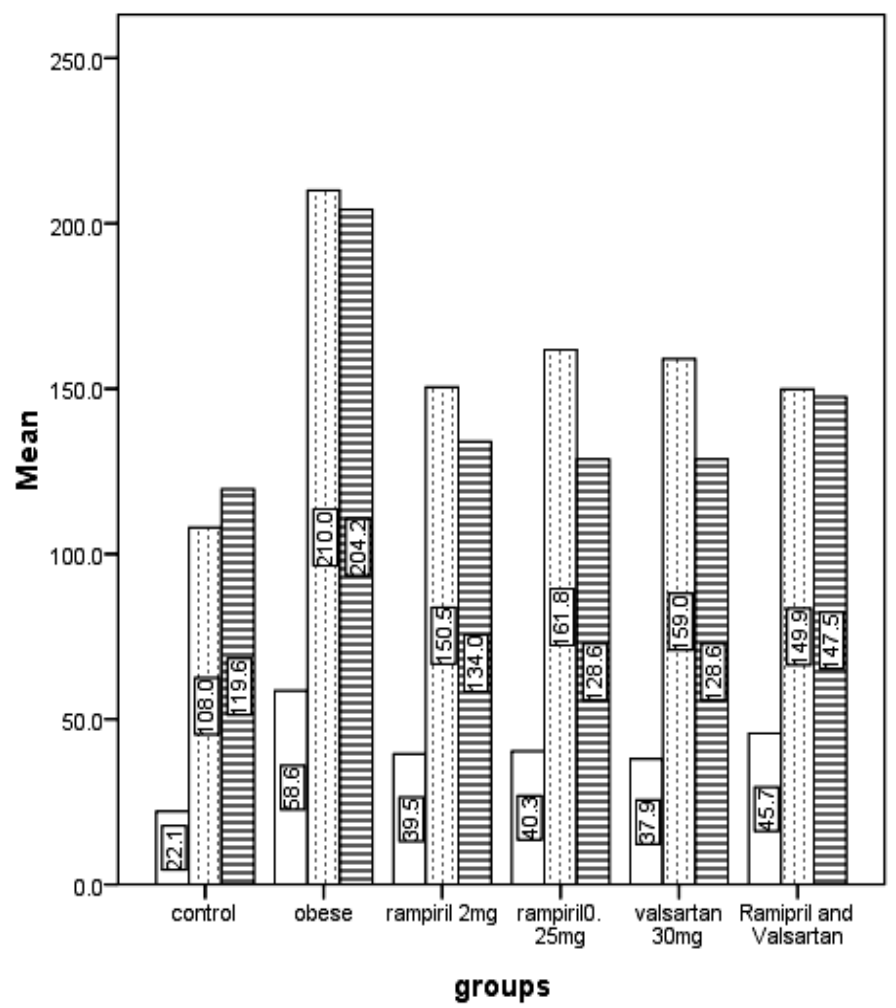

Figure 2. Levels of advanced oxidation protein products (AOPPS) in serum, kidney and aortic tissues

Obesity was associated with significantly higher activities of ACE in blood, kidney and aortic tissues (43.26 $\pm 1.00 \mathrm{nmol}$ His-leu/min/ml, 15.22 $\pm 0.52 \mathrm{nmol}$ His$\mathrm{leu} / \mathrm{min} / / \mathrm{mg}$ protein and $229.8 \pm 1.58 \mathrm{nmol} \mathrm{His}-\mathrm{leu} / \mathrm{min} / \mathrm{mg}$ protein) compared to their corresponding values in the control group $(20.66 \pm 0.5 \mathrm{nmol}$ His-leu/min $/ \mathrm{ml}, 8.62 \pm 0.23$ $\mathrm{nmol} \mathrm{His-leu} / \mathrm{min} / \mathrm{mg}$ protein and $1178 \pm 1.88 \mathrm{nmol}$ Hisleu/min/mg protein) as illustrated in table 5 and figure 3 .
Treatment with ramipril only (groups III and IV) and in combination with valsartan (group VI) prevented significantly the increase in the activity of ACE in obese animals when compared to untreated group II. On the other hand, treatment with valsartan alone produced no significant effect on its activity. Moreover it was noted that there was no significant differences in ACE activity levels between groups III, IV and VI. 
Table 5. Levels of the activity of angiotensin converting enzyme (ACE) in serum (nmol His-leu/min/ml), kidney and aortic tissues (nmol His-leu/min/mg protein) expressed in mean \pm S.E

\begin{tabular}{lllllll}
\hline ACE activity & Group I & Group II & Group III & Group IV & Group V & Group VI \\
\hline Serum & $20.66 \pm 0.5^{\#}$ & $43.26 \pm 1.0^{*}$ & $11.86 \pm 0.48^{* \#}$ & $15.06 \pm 0.27^{* \#}$ & $45.56 \pm 1.23^{*}$ & $14.33 \pm 0.3^{* \#}$ \\
Kidney tissues & $8.62 \pm 0.3^{\#}$ & $15.22 \pm 0.52^{*}$ & $5.52 \pm 0.19^{* \#}$ & $6.12 \pm 0.14^{* \#}$ & $14.59 \pm 0.53^{*}$ & $6.38 \pm 0.19^{* \#}$ \\
Aortic tissues & $117.8 \pm 1.88^{\#}$ & $229.8 \pm 1.58^{*}$ & $112.3 \pm 1.32^{* \#}$ & $112.3 \pm 1.34^{* \#}$ & $219.8 \pm 1.44^{* \#}$ & $116.2 \pm 1.78^{* \#}$ \\
\hline
\end{tabular}

* Significant when compared to the corresponding values in group I

\# Significant when compared to the corresponding values in group II

All measured parameters showed no significant difference between group III (received $2 \mathrm{mg} / \mathrm{kg} /$ day ramipril) and group IV (received $0.25 \mathrm{mg} / \mathrm{kg} /$ day ramipril) except for the level of AGEs in aortic tissues and the level of AOPPs in renal tissues. Furthermore, the obtained results indicates that the combined administration of ramipril $(0.25$

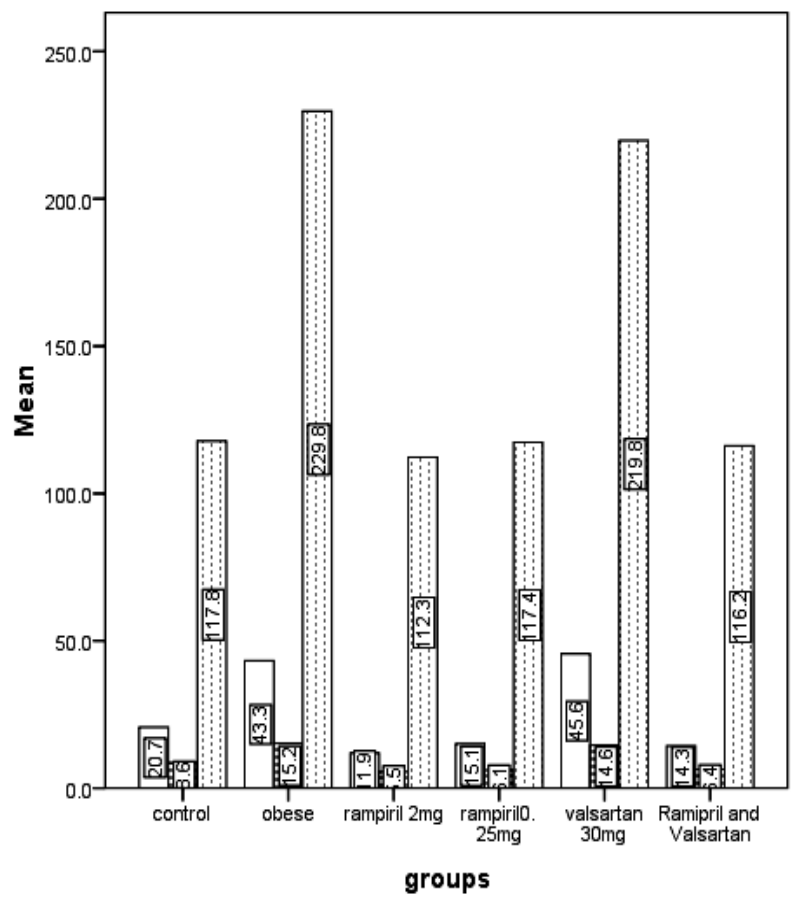

$\mathrm{mg} / \mathrm{kg} / \mathrm{day}$ ) and valsartan in group VI produced additive significant reduction in serum and tissues levels of both AGEs and AOPPs compared to group III (ramipril 2 $\mathrm{mg} / \mathrm{kg} /$ day), group IV (ramipril $0.25 \mathrm{mg} / \mathrm{kg} /$ day) and group $\mathrm{V}$ (valsartan alone).

Figure 3. Levels of the activity of angiotensin converting enzyme (ACE) in serum, kidney and aortic tissues

\section{Discussion}

A high fat diet intake is considered to be a major factor in the development of insulin resistance and obesity [36]. The feeding of high fat diet to rats was proved to be a useful model of putative effects of the dietary fat in humans, and there is an evidence of reduced induced insulinmediated glucose metabolism in muscle and adipose tissues isolated from animals fed a high fat diet [37]. Female laboratory rats had growth curves that become stationary with age, and with decreasing the rate of weight gain by time, make it easier to detect any experimental effects on body weight. In contrast, male albino rats show a continual linear increase in growth with age making it more difficult to detect the effect of diet on weight [38].

Higher levels of blood glucose and serum insulin were detected in obese female rats in this study, indicating the development of insulin resistance (IR) which agrees with many studies [36] [37]. As indicated above the significant decrease in insulin levels following the treatment with ramipril is also supported by the previous results obtained by Valensi et al. [38] who suggested that low dose of ramipril can increase insulin action and improves insulin sensitivity in obese subjects. Wang et al. [24] demonstrated that ramipril had a tendency to improve whole body insulin sensitivity with respect to enhancement of glucose uptake in skeletal muscles, and it also caused improvement of IR that accompanied high fat diet and obesity. Conversely, a reported data suggested the lack of ramipril on fasting glucose, insulin, or IR [39] which was attributed to the short one week study time.

The lipid profile in the current study showed that obese animals had higher levels of TGs, TC and LDL-C with lower HDL-C than the control group which agrees with the results obtained by Boivin and Deshaies [40] who found that high fat diet induced obesity in rats produces 
dyslipidemia with increased serum levels of TGs, TC and LDL-C as well as higher levels of glucose and insulin in the blood. As illustrated above, treated animals with ramipril, valsartan and their combination exhibited, although, mild but significant, lowering effect on both TC and LDL-C levels without any significant effects on TGs and HDL-C levels compared to the obese untreated group. This finding is consistent with many previous results reported that both ramipril [41], and valsartan can produce a considerable beneficial effects on lipid profile by lowering TC and LDL-C levels [42].

The present study revealed that obesity was associated with activation of ACE in kidneys, aortic tissues and serum, which agrees with other studies that found positive correlation between plasma levels of angiotensin \& ACE and activation of rennin angiotensin system (RAS) [43]. Obesity was associated with significant elevation in both serum and tissue levels of AGEs see table 3. The increased in AGEs levels could be explained by the significant elevation of blood glucose level, and IR in the same animals. It has been stated that prolonged exposure of proteins or lipids leads to nonenzymatic glycation of proteins leading to the formation of variety of chemically modified proteins known as AGEs [44]. Furthermore, it has been proposed that auto-oxidation of glucose may be the more likely candidate as the source of reactive oxygen in diabetes. Auto-oxidation produces glyoxal and arabinose from glucose along with superoxide radical and hydrogen peroxide, providing a logical route for the formation of AGEs and ROS via the Millard reaction [45]. The pathogenisity of AGEs is related to their irreversible formation and ability to accumulate to tissues, with formation of collagen cross-links resulting in increase tissue rigidity [13]. Alternative mechanisms that might explain AGEs generation of reactive oxygen species (ROS) involve the interaction of AGEs with their receptor, leading to generation of ROS through stimulation of membrane bound NADH/NADPH oxidase, which is an enzyme system that use NADH and/or NADPH as substrates for the production of superoxide anions, this system, also, is activated in response to angiotensin II [16] [46]. Therefore, in conditions in which the local and/or systemic rennin angiotensin system is activated, one would expect superoxide production to be increased [47]. Superoxide itself however is chemically inert but in combination with nitric oxide (NO), it generates the ROS, peroxynitrite $\left(\mathrm{OONO}^{-}\right)$. A characteristic reaction of $\mathrm{OONO}^{-}$is the nitration of protein-bound tyrosine residues enhancing protein and lipid peroxidation [47]. Thus, excess vascular superoxide has the dual effect of reducing the bioactivity of NO and promoting vascular oxidative stress. Furthermore, superoxide is subjected to dismutation by superoxide dismutase producing $\mathrm{H}_{2} \mathrm{O}_{2}$, an agent typically associated with lipid and protein oxidation in the presence of transition metals [48]. In the present study, the increased levels of AOPPs in obese animals with higher levels of AGEs and ACE could be explained on the basis of these data. The decreased both tissue and blood levels of AGEs and AOPPs in group III after using ramipril might be due to its role in interruption of the RAS. Multiple mechanisms have been postulated to explain the protective effects of these agents. It is conceivable that blockade of the RAS alone may have effects on AGEs accumulation and consequently reducing oxidative stress, it was reported that angiotensin converting enzyme inhibitor (ACEI) have been shown to improve the antioxidant defense with the evidence that ramipril administration results in a mild decline in AGEs and AOPPs [49]. Moreover, previous invitro study on culture cells exposed to AGEs demonstrated a reversal in AGE-induced collagen production by the ACEI ramipril and the increased expression of AGEs receptors were, also attenuated by ACE inhibition [50]. Additionally, ACE inhibitors represent a novel antioxidant strategy that targets oxidative stress as its source, and limits vascular $\mathrm{NAD}(\mathrm{P}) \mathrm{H}$ oxidase stimulation, thus preventing increased superoxide flux associated with activation of the RAS and, also, ACE inhibition of protein oxidation through decreased formation of peroxynitrite and reduced AGEs formation [51].

Treatment with valsartan reduces tissue and blood AGEs levels, see figure 1, which agrees with those results obtained by Miyata et al. [50]. Their results showed that the blockade of angiotensin II AT (1)-receptor stimulate the differentiation of adipocytes and the storage of free fatty acids (FFA) leading to the reduction of plasma FFA and producing a decrease of the IR. Recently, it was proved that valsartan can inhibit angiotensin II-induced peroxynitrite formation [52] and exhibit a significant improvement in insulin-dependent glucose uptake by skeletal muscles, also, it can reduce the whole body IR in the models of rats by over-expressing angiotensin II with decreased superoxide production, indicating that oxidative stress plays an important role in angiotensin II-mediated IR [53].

Recent studies showed that administration of valsartan to type 2 diabetic and atherosclerotic animal models significantly increased the expression of NAD $(\mathrm{P}) \mathrm{H}$ oxidase with the enhancement of superoxide anions production, also, there was an inhibition of the oxidative stress and partial restoration of the decreased insulin contents in islets without any effect on cholesterol concentration in the atherosclerotic animal model [51]. Forbes et al. [26], reported that renoprotective doses of valsartan are associated with a significant reduction of tissue and plasma AGEs.

The combined therapy of both ramipril and valsartan, shown earlier, has favorable results over the monotherapy of either ramipril or valsartan alone, as it reduces plasma and tissue levels of AGEs and AOPPs. The use of a combination of an ACEI and angiotensin II receptor blocker was principally to obtain the broadest and the most efficient blockade of the effects of angiotensin rennin system (RAS). The main idea behind the use of such a combination is based upon the escape from angiotensin converting enzyme (ACE) effects, a mechanism by which the levels of angiotensin II and aldosterone return to the 
pretreatment levels despite continuous treatment with an ACEI. Also, the two drugs combination would diminish the ACE escape phenomenon, while, preserving the effect on bradykinin degradation from the ACEI [54]. It is well established that ACEI potentiates the effects of exogenous bradykinin by inhibiting its breakdown, while, there was no evidence that angiotensin II type 1 receptor antagonists can do the same [9].

Furthermore, Yagi et al. [55] demonstrated that combination therapy of ACE inhibitors and angiotensin II receptor blockers (either in high or low doses) exerts an extra inhibitory effect on the oxidative stress parameters, seemingly through an increase in production and bioavailability of NO from the endothelium. Moreover, their combination seems to provide better long-term renoprotection than monotherapy [10].

The present study showed that there was no significant difference between groups of animals which were administrated with ramipril and those administrated with valsartan. In a comparative study of four weeks therapy with either ramipril or losartan, it was shown that they increased extracellular superoxide dismutase activity and the bioavailability of NO to a similar extent [24].

Although early results suggested an equivalence between ACEI and angiotensin II effects, but, the later offers the potential of complete blockade of angiotensin II, selective inhibition of the AT1 receptor and specificity for the RAS, with the undisputed advantage of excellent tolerability [56].

\section{Conclusion}

Obesity is associated with dyslipidemia and elevated levels of blood glucose, insulin, AGEs, AOPPs and ACE activity. Treatment of animals with a high dose or a submaximal antihypertensive dose of ramipril or valsartan produces a decrease in TC and LDLC levels, markedly decreases AGEs formation and reduces oxidative stress by lowering AOPPs levels. Valsartan or ramipril, which are currently used as antihypertensive drugs, could be of beneficial use in cases of obesity with or without diabetes. The combination of both drugs produces a marked reduction in those parameters compared to the use of valsartan or ramipril individually. Thus, their combination has more therapeutic effects than the monotherapy with ACEI or AT1 receptor blocker.

\section{References}

[1] Aronne LJ. Epidemiology, morbidity and treatment of overweight and obesity. J. Clin. Psychiatry. 2001; 62:13-22

[2] Zanella MT, Kohlmann O and Ribewiro AB. treatment of obesity hypertension and diabetes syndrome. Hypertension. 2002; $38: 705$

[3] Lopez de Fez, CM, Gaztelu MT, Rubio T, Castano A, and Navar. Mechanisms of hypertension in obesity. An. Sist. Sanit. 2004; 27:211-219
[4] Mazzolai L, Nussberger J, Aubert JF, Brunner DB, Gabbiani G, Brunner HR, and Pedrazzini T. Blood pressureindependent cardiac hypertrophy induced by locally activated rennin -angiotensin system. Hypertension. 1998; $31: 1324$

[5] Engeli S, Negrel R and Sharm G. Physiology and pathophysiology of the adipose tissue Rennin-Angiotensin System. Hypertension. 2000; 35: 1270-1275

[6] Hooper NM and Turner AJ. An ACE structure. Nat. Struct. Biol. 2003; 10: 155-157

[7] Riordan JF. Angiotensin-1-converting enzyme and its relatives. Genome Biol. 2003; 4: 225-231

[8] Wysocki YMJ, Naaz P, Salabat MR, Michael S, Pointe L and Battle D. Increased ACE 2 and decreaed ACE protein in renal tubules from diabetic mice: a reno- protective combination?. Hypertension. 2004; 43: 1120-1126

[9] Anderson NH, Poulsen PL, Knudsen ST, Poulsen SH, Hansen, Helleberg, KW and Mogensen CE. Long-term dual blockade with candesartan and lisinopril in hypertensive patients with diabetes. Diabetes Care. 2005; 28: 273-277

[10] Laverman GD, Remuzzi G and Ruggenenti P. ACE inhibition versus angiotensin receptor blockade: which is better for renal and cardiovascular protection?. J. Am. Soc. Nephrol. 2004; 15: S64

[11] Fuller JH, Shipley MJ, Rose G, Jarrett RJ and Keen H. Coronary heart disease risk and impaired glucose tolerance the Whitehall study. Lancet. 1980; 1: 1373

[12] Mitsuhashi T, Nakayama H, Itoh T, Kuwajima S, Aoki S, Atsumi $T$ and Koike $T$. Immunochemical detection of advanced glycation end products of renal cortex from streptozotocin-induced diabetic rats. Diabetes 1993; 42:826832

[13] Turk Z, Sesto M, Skodiar J, Ferencak G, Pokupec R, Turk N and Rukavina S. Products of advanced glycation in patients with type 2 diabetes and vascular disease. Assoc. Clin. Biochem., 2003; 40: 552-559

[14] Huang JS, Guh JY, Chen HC, Hung WC, Lai YH and Chuang LY. Role of receptor for advanced glycation end product (RAGE) and the JAK/STAT signaling pathway in AGE-induced collagen production in NRK-49F cells. J. Cell Biochem. 2001; 81:102

[15] Schmidt AM, Yan SD, Wautier JL and Stern D. Activation of receptor for advanced glycation end products: a mechanism for vascular dysfunction in diabetic vasculopathy and atherosclerosis. Circulation Research 1999; 84: 489-497

[16] Wautier MP, Chappey O, Corda S, Stern DM, Schmidt AM and Wautier JL. Activation of NADPH oxidase by ACE links oxidant stress to altered gene expression via RAGE. AM. J. Physiol. Endocrinol. Metab. 2001; 280: E685-E694

[17] Stocker R, John F and Keaney JR. Role of oxidative modifications in atherosclerosis. Physiol. Rev. 2004; 84:1381-1478

[18] Kalousova M, Zima T, Tesar V and Lachmanova J. Advanced glycation end products and advanced oxidation protein products in hemodialyzed patients. Blood Purif. 2001; 20: 531-536 
[19] Fialova L, Kalousova M, Soukupova J, Malbohan I, Krofta L, Mikulikova L, Horejsova H, Stipek S and Zima T. Levels of advanced oxidation protein products (AOPP) in the forst trimester of pregnancy. Sb Lek. 2003; 104(1): 95-102

[20] Ylma IA, Akcay T, Akatay U, Telci A, Ataus S and Yalcin V. Relation between bladder cancer and protein oxidation. International Urology and Nephrology 2003; 35: 345-350

[21] Davies M, Brown B, Cauka R, Howkin C, Headless h, Woods A, Martin R and Philip M. Mechanism of protein oxidation. EPR Group 2003; 4:1-2

[22] Forbes JM, Cooper ME, Thallas V, Burns WC, Thomas MC, Brammar GC, Lee F, Grant SL, Burrell LA, Jerums G and Osicka TM. Reduction of the accumulation of advanced glycation end products by ACE inhibition in experimental diabetes. Diabetes 2002; 51:3274-3282

[23] Leiter LA and Lewanczuk RZ. Of the rennin angiotensin system and reactive oxygen species type II diabetes and angiotensin II inhibition. AM. J. Hypertension 2005; 18: $121-128$

[24] Wang CH, Leung N, Lapointe N, Szeto L, Uffelman KD, Giacca A, Rouleau JL and Lewis GF. Vasopeptidase inhibitor omapatrilat induces profound insulin sensitization and increases myocardial glucose uptake in Zucker fatty rats: Studies comparing a vasopeptidase inhibitor, ACE inhibitor and angiotensin II type I receptor blocker. Circulation 2003; 107: 1923

[25] Mervaala EM, Teravainen TL, Malmberg L, Laakso J, Vapaatalo $\mathrm{H}$ and Karppanen $\mathrm{H}$. Cardiovascular effects of a low dose combination of ramipril and felodipine in spontaneously hypertensive rats. BR. J. Pharmacol.,m 1997; 121: $503-510$

[26] Forbes JM, Thomas MC, Thrope SR, Alderson NL and Cooper ME. The effects of valsartan on the accumulation OF circulating and renal advanced glycation end products in experimental diabetes. Kidney Int. (Suppl.) 2004; 92:S105

[27] Lemmonnier D. Effect of age, sex and site on the cellularity of adipose tissue in mice and rats rendered obese by high fat diet. J. Clin. Invest. 1972; 51: 2907

[28] Ikemoto S, Talahasi M, TsunodaN, Maruyama K, Itakura H and Ezaky O. High fat diet induced hyperglycemia and obesity in mice: differential effects of dietary oils. Metabolism 1996; 45: 1539

[29] Bradford MM. A rapid and sensitive method for the quantitation of microorganisms' quantities of protein utilizing the principle of protein-dye binding. Anal. Biochem. 1976; $72: 248$

[30] Varley H, Gowenlock H and Bell M. Determination of plasma glucose by oxidase method. In practical Clinical Biochemistry Vol. $2,5^{\text {th }}$ edition, William Medical Books Ltd, London. 1980; 385-396

[31] Engvall E, Jonsson K, and Perlman P. Enzyme- linked immunosorbent assay. II. Quantitative assay of protein antigen, immunoglobulin G, by means of enzyme-labeled antigen and antibody-coated tubes. Biochim. Biophys. Acta $1971 ; 251: 427-434$

[32] Nakayama H, Mitsuhashi T, Kuwajima S, Aoki S, Kuroda Y, Itoh $\mathrm{T}$ and Nakagawa $\mathrm{S}$. Immunochemical detection of advanced glycation end products in lens crystalline from streptozotocin-induced diabetic rat. Diabetes 1993; 42: 345-
350

[33] Edwards CA and O'Brein JR. Modified assay for determination of hydroxyproline in tissue hydrolysate. Clin. Chim. Acta 1980; 104: 161-167

[34] Witko-Sarat V, Friedlander M, Capeillere-Blandin C, Nguyen-Khoa T, Nguyen AT, Zingraff J, Jungers $\mathrm{P}$ and Descamps-Latscha B. Advanced oxidation protein products as a novel marker of oxidative stress in uremia. Kidney Int. 1996; 49: 1304-1313

[35] Oleveira EM, Santos RAS and Krieger JE. Standardization of a fluorimetric assay for determination of tissue angiotensin converting enzyme activity in rats. Braz. J. Med. Biol. Res. 2000; 33:755

[36] Gaundleger ML and Wthenen S. Decreased insulin binding, glucose transport and glucose metabolism in soleus muscle of rats fed a high fat diet. Diabetes 1992; 31: 232-237

[37] Salans LB, Foley LT, Wardzala LJ and Cushman SW. Effects of dietary composition on glucose metabolism in rat adipose cells. Am. J. Physiol. 1981; 240: E175-E183

[38] Valensi P, Derobert E, Genthon R and Riou JP. Effect of raipril on insulin sensitivity in obese patients. Time course study of glucose infusion rate during euglycemic hyperinsulinemic clamp. Diabetes Metab. 1996; 22: 197-200

[39] Brown NJ, Kumar S, Painter CA and Vaughan DE. ACE inhibition versus angiotensin type I receptor antagonism. Hypertension 2002; 40: 1-2

[40] Boivin A and Deshaies Y. Dietary rat models in which the development of hypertriglyceridemia and that of insulin resistance are associated. Metabolism 1995; 44(12): 15401547

[41] Schnack C, Hoffmann W, Hopmeier P and Schernthaner G. Renal and metabolic effects of 1-year treatment with ramipril and atenolol in NIDDM patients with microalbuminuria. Diabetologia 1996; 39:1611-1616

[42] Veliga-Asimi $Z$ and Heljic B. The effects of valsartan on lipid profile in normotensive type 2 diabetic patients. Med. Arh. 2005; 9:311

[43] Engeli S, Negrel R and Sharm, G. Physiology and Pathophysiology of the adipose tissues Rennin-Angiotensin System. Hypertension 2000; 35:1270-1275

[44] Tan K, CB, Chow WS, Tam S, Bucala R and Betterridge J. Association between acute phase reactants and advanced glycation end products in type 2 diabetes. Diabetes Care 2004; 27 : 223-228

[45] Wolff SP. Diabetes mellitus and free radicals: Free radicals, transition metals and oxidative stress in the etiology of diabetes mellitus and complications. Br. Med. Bull. 1993; 49:642-652

[46] Hayek T, Pavlotzky E, Hamoud S, Coleman R, Keidar S, aviram M and Kaplan M. Tissue ACE deficiency leads to a reduction in oxidative stress and in atherosclerosis: Studies in ACE-Knockout mice type 2 diabetes. Atherosclerosis, thrombosis and Vascular Biology 2003; 23: 2090-2096

[47] Onozato ML, Tojo A, Goto A, Fujita T and Wilcox CS. Oxidative stress and nitric oxide synthase in rat diabetic nephropathy: Effects of ACE1 and ARB. Kidney Int. 2002; 61: 186 
[48] Zou MH, Shi C and Cohen RA. High glucose via peroxynitrite causes tyrosine nitration and inactivation of prostacyclin synthase that is associated with thromboxane/prostaglandin $\mathrm{H}_{2}$ receptor mediated apoptosis and adhesion molecule expression in cultured human aortic endothelial cells. Diabetes 2002; 51:198-203

[49] Sebekova K, Gazdikova K, Syrova D, Blazicek P, Schinzel R, Heidland A, Spustova A and Dzurik R. Effects of ramipril in nondiabetic nephropathy: improved parameters of oxidative stress and potential modulation of advanced glycation end products. J. Human hypertension 2003; 17: 265-270

[50] Miyata T, Strihou CY, Ueda Y, Ichimori K, Inagi R, Onogi H, Ishikawa N, Nangaku M and Kurokawa K. Angiotensin II receptor antagonists and ACE inhibitors lower invitro the formation of advanced glycation end products; Biochemical mechanisms. J. Am. Soc. Nephrol., 2002; 13:2478-2487

[51] Nakayama M, Inogushi T, Obayashi K, Sumimoto H and Nawata $H$. increased expression of $\mathrm{NAD}(\mathrm{P}) \mathrm{H}$ oxidase in islets of animal models of type 2 diabetes and its improvement by an AT1 receptor antagonist. Biochem.biophys. Res. Common. 2005; 332(4): 927-933
[52] Imanishi T, Hano $\mathrm{T}$ and Nishio $\mathrm{H}$. Angiotensin II accelerates endothelial progenitor cell senescence through induction of oxidative stress. J. Hypertension 2005; 231: 97-104

[53] Blendea MC, Jacobs D, Stump CS, McFarlane SI, Ogrin C, Bahtyiar G, Stas S, Kumar P, Sha Q, Ferrario CM and Sowers JR. Abrogation of oxidative stress improves insulin sensitivity in the Ren-2 rat model of tissue angiotensin II over-expression. Am. J. Physiol. Endocrinol. Metab. 2005; 288: E353

[54] Davie AP, Dargie HJ and McMurray JJ. Role of bradykinin in the vasodilator effects of losartan and enalapril in patients with heart failure. Circulation 1999; 00:268-273

[55] Yagi S, Morita T and Katayama S. Combined treatment with an AT1 receptor and ACE1 has an additive effect on inhibiting suppression of oxidative stress. Hypertens. Res. 2004; $27: 129$

[56] McInnes GT. Clinical potential: of ACEI or angiotensin II antagonist? J. Hypertens. 2001; (suppl.) 19(1): 561- 567 